\section{KOMUNIKASI PEMASARAN \\ SEBAGAI \\ METODE PROMOSI UNTUK USAHA \\ KECIL MENENGAH}

Adhi Gurmilang

Program Studi Ilmu Komunikasi,

Universitas Pembangunan Jaya

Adhi.gurmilang@upj.ac.id

\begin{abstract}
Abstrak
Seorang wirausahawan merakit dan menyatukan semua sumber daya yang dibutuhkan yaitu uang, manusia, model bisnis, strategi dan kemampuan untuk mengambil risiko untuk mengubah temuan baru menjadi sebuah bisnis yang dapat dilaksanakan. Sebuah bisnis mengacu kepada sebuah bauran pemasaran yang terdiri dari produk, harga, tempat dan promosi. Sebagai bauran pemasaran, promosi memiki beberapa tantangan terhadap efektivitas dan efisiensi pesan pemasaran yang ingin disampaikan. Untuk itu, muncul konsep komunikasi pemasaran terpadu yang menggabungkan beberapa taktik komunikasi pemasaran menjadi terpadu untuk meningkatkan efektivitas dan efisiensi pesan pemasaran.
\end{abstract} Pengetahuan, pemahaman dan pelaksanaan komunikasi pemasaran terpadu akan membantu seorang wirausawahan untuk membantu pemasaran merek yang dimilikinya. Tulisan ini bertujuan untuk melakukan kajian teoritis antara kewirausahaan dan komunikasi pemasaran terpadu sebagai metode promosi pemasaran. Apabila dilakukan dengan komprehensif, komunikasi pemasaran terpadu akan membantu seorang wirausahawan untuk membantu ia memperkenalkan, membentuk kesan positif dan mempertahankan pelanggannya terhadap merek yang dimilikinya.

Kata kuci: Komunikasi, Pemasaran, Wirausaha

\section{Abstract}

An entrepreneur assembles and unites all required resources are money, manpower, business model, strategy and the ability take risks develop a new business. A business refers to a marketing mix consisting of product, price, place and promotion. As the marketing mix, promotional refers to the challenges to the effectiveness and efficiency of marketing messages. To that end, emerge the concept of integrated marketing communications that combine several into an integrated marketing communications tactics to improve the effectiveness and efficiency of marketing messages. Knowledge, understanding and implementation of integrated marketing communications will help a entrepreneur to help the communication of its brand. This paper 
aims to perform a theoretical study of the entrepreneurial and integrated marketing communications as a method of marketing promotions. The integrated marketing communications will help an entrepreneur to help it introduce, forming a positive impression and retain customers for its brand.

Keyword: Communication, Marketing, Preneurship

\section{PENDAHULUAN}

\subsection{Latar Belakang}

Salah satu dasar keilmuan yang paling berhubungan dengan kewirausahaan adalah pemasaran. Menurut American Marketing Association, pemasaran adalah sebuah proses perencanaan dan pelaksanaan pembuatan, pembuatan harga, promosi dan distribusi meliputi ide, produk, dan jasa untuk menciptakan pertukaran yang memberikan kepuasan kepada individu dan organisasi (Duncan, 2003). Pakar pemasaran terkenal, Kotler bahkan menyederhanakan pemasaran menjadi sebuah bauran pemasaran yaitu produk, harga, tempat penjualan dan promosi (Kotler, 1996). Promosi adalah sebuah usaha untuk menjual sebuah produk atau jasa dalam sebuah proses penjualan mulai dari materi presentasi yang dibawa oleh seorang salesperson sampai iklan televisi atau di surat kabar yang mendorong konsumen yang memiliki pemikiran yang positif mengenai produk atau jasa yang sedang diiklankan. Namun seiring perkembangan zaman, berbagai tantangan muncul terhadap promosi untuk mencapai efektivitas dan efisiensi disebabkan promosi yang tidak lagi menarik perhatian konsumen, perkembangan teknologi informasi dan komunikasi yang merubah media sebagai tempat melakukan promosi, biaya promosi yang mahal sekali dan tidak jarang menguras sebagian besar biaya promosi dan lain sebagainya (Belch \& Belch, 2003). Untuk itulah, Schultz (1993) seorang pakar komunikasi melahirkan konsep komunikasi pemasaran terpadu yang menggabungkan berbagai taktik komunikasi pemasaran mulai dari advertising, public relations, direct marketing, special event, sponsorship sampai customer service. Konsep ini bertujuan untuk memaksimalkan komunikasi pemasaran dari segi efektivitas pesan sampai efisiensi biaya sehingga tujuan komunikasi pemasaran yang diinginkan tercapai.

Bagi seorang calon wirausahawan, konsep pemasaran seringkali dianggap hanyalah dilakukan oleh perusahaan besar. Padahal konsep pemasaran merupakan salah satu unsur penting dalam membangun brand 
yang dimiliki oleh calon wirausahawan tersebut. Sayangnya sebagai salah satu komponen pemasaran, promosi seringkali dianggap sebagai komponen yang kurang begitu penting. Calon wirausawahan sudah menghabiskan sebagian besar sumber daya yang dimilikinya untuk membangun produk atau jasanya, penghitungan harga mulai dari biaya pembuatan sampai penetapan harga jual dan tempat menjual. Promosi sering menjadi dilupakan sehingga ketika berinteraksi dengan konsumen, brand tersebut menjadi kesulitan untuk memperkenalkan dirinya, membangun kesan positif sampai memelihara kesan yang diinginkan. Untuk itu, penting bagi seorang calon wirausahawan untuk mengenal konsepkonsep komunikasi pemasaran yang akan membangun hubungan brand yang dimilikinya dengan konsumen yang ada.

\subsection{Rumusan Masalah}

Untuk itu, tulisan ini berusaha untuk melakukan kajian teoritis mengenai bagaimana sebuah konsep komunikasi pemasaran terpadu dapat menjadi salah satu senjata penting seorang calon wirausahawan dalam membangun brand yang dimilikinya.

Pada tulisan ini, tinjauan teoritis yang akan dipaparkan adalah kewirausahaan, pemasaran dan kewirausahaan, komunikasi pemasaran terpadu. Selain itu, sebuah pembahasan mengenai penerapan komunikasi pemasaran terpadu mengenai sebuah brand akan dipaparkan secara jelas. Pada akhir tulisan, kesimpulan dan saran mengenai kewirausahaan dan komunikasi pemasaran terpadu menjadi penutup tulisan ini.

\section{TINJAUAN TEORITIS}

\subsection{Definisi Entrepreneurship}

Kata entrpreneurship berasal dari bahasa Perancis entre yang berarti "antara" dan prendre, berarti "mengambil." Kata ini digunakan untuk menggambarkan orangorang yang berani mengambil risiko antara pembeli dan penjual atau yang berani untuk menempuh sebuah kehidupan. Penemu dan wirausahawan berbeda satu sama lain. Seorang penemu menciptakan sesuatu yang baru. Seorang wirausahawan merakit dan menyatukan semua sumber daya yang dibutuhkan yaitu uang, manusia, model bisnis, strategi dan kemampuan untuk mengambil risiko untuk mengubah temua baru menjadi sebuah bisnis yang dapat dilaksanakan. Definisi entrepreneurship adalah proses di mana individu mengejar kesempatan tanpa mempertimbangkan sumber daya yang sedang mereka miliki. Definisi lainnya adalah sebuah seni yang mengubah ide 
menjadi sebuah saua. Intinya, perilaku seorang wirausahawan mengenali kesempatan dan mewujudkan sebuah ide menjadi sebuah kenyataan. Perilaku ini dapat dicapai secara individu maupun kelompok dan membutuhkan kreativitas, dorongan kuat dan keberanian untuk mengambil risiko (Dafna, 2011).

\subsection{Motivasi Menjadi Wirausaha}

Ada tiga alasan utama ketika seseorang memutuskan untuk menjadi wirausahawan dan mulali membangun perusahana mereka untuk menjadi pemilik usaha, mengejar ide dan mendapatkan kepuasan finansial sebagai berikut, (1) Menjadi pemilik usaha: Menjadi pemilik usaha adalah salah alasan utama namun tidak berarti bahwa menjadi seorang wirausahawan adalah seseorang yang sulit bekerjasama atau sulit untuk menerima otoritas. Sebaliknya banyak wirausahawan ingin menjadi boss untuk diri sendiri karena mereka memiliki ambisi untuk memiliki perusahaan sendiri atau frustrasi terhadap pekerjaaan mereka. Ketika menjadi pemilik usaha adalah sebuah realisasi pencapaian personal atau professional, (2) Mengejar ide baru: Alasan lainnya menjadi seorang wirausahawanwan adalah mengejar ide pribadi. Ada beberapa orang yang memiliki ide baru untuk produk dan jasa dan memiliki keinginan untuk mewujudkan ide baru tersebut. Para wirausahawanwan yang berasal dari serorang eksekutif korporasi biasanya memiliki ide yang relevan dengan perusahaan namun sayangnya perusahaan tersebut menolak ide tersebut. Akibatnya, banyak ide yang baik namun tidak dapat dilaksanakan sehingga para pengagas ide tersebut memilih untuk keluar perusahaan, membangun perusahaan sendiri untuk mewujudkan ide tersebut menjadi nyata, (3) Kepuasan finansial: Motivasi mengejar kepuasan finansial dengan menjadi seorang wirausahawan adalah sebuah motivasi sekunder dibandingkan dua motivasi yang telah dipaparkan sebelumnya. Menjadi seorang wirausahawan adalah mendapatkan sebuah kebebasan finansial dibandingkan menjadi seorang eksekutif korporasi. Kebebasan finansial merupakan sebuah konsekuensi ketika sebuah wirausahawan dijalankan dan mendapatkan keuntungan (Dafna, 2011).

\subsection{Entrpreneurship Dan Pemasaran}

Pemasaran adalah bentuk tradisional yang merupakan proses perencanaan yang muncul dari pengenalan pasar oleh penelitian dan apakah yang dapat ditawarkan kepada pasar. Usaha kecil menengah (UKM) merupakan aktivitas 
informal, tidak direncanakan yang bergantung kepada intuisi dan semangat dari pemilik sekaligus pengelola yang bertujuan untuk mewujudkan UKM tersebut. Tidak heran bahwa pemilik UKM sering menganggap pemasaran tidak sebagai prioritas dibandingkan dengan fungsi lainnya dan sering menganggap pemasaran merupakan hal bagi perusahaan besar. Kewirausahaan dan pemasaran merupakan dua hal yang berbeda pada kajian manajen. Omura et. al (1993) bahkan menganggap dua hal tersebu dapat saja berbeda namun saling berkaitan satu sama lain dan hal ini terdiri dari kondisi pasar dinamis dan kewirausahaan menangkap peluang dari pasar tersebut. Hal kedua adalah pasar statis dimana kewirausahaan berusaha untuk menciptakan kebutuhan baru. Seperti disebutkan di atas bahwa pemasaran sering dianggap sebagai fungsi bisnis sama seperti manufaktur dan keuangan. Sulit sekali bagi perusahaan perusahaan kecil untuk memisahkan fungsi ini karena perusahaan ini hanya mempekerjakan karyawan dalam jumlah yang sangat sedikit dan sering mereka tidak memahami pemasaran. Menurut Gilmore (2001) pemasaran dalam UKM menekankan kepada pembentukan jaringan kerjasama atau kombinasi antara transaksi, hubungan, interaksi dan jaringan pemasaran (Gungaphul, M., \& Boolaky, M 2009).
Dalam membangun sebuah wirausaha, dibutuhkan sebuah model bisnis yang berlandaskan konsep pemasaran. Menuruf American Marketing Association, pemasaran adalah proses perencanaan dan pelaksanaan pembuatan, pembuatan harga, promosi dan distribusi meliputi ide, produk, dan jasa untuk menciptakan pertukaran yang memberikan kepuasan kepada individu dan organisasi (Duncan, 2003). Fokus pemasaran adalah terjadinya pertukaran, antara dua pihak, keinginan untuk memberikan sesuatu, dan saling berkomunikasi satu sama lain. Konsep pemasaran ini disederhanakan oleh Kotler menjadi konsep marketing mix yaitu product, place, promotion dan price. Seringkali konsep marketing mix disebut 4P yaitu (1) Produk: Produk adalah tawaran untuk memuaskan kebutuhan dari perusahaan. Tawaran ini dapat berbentuk barang, jasa, atau campuran keduanya. Produk menggambarkan bagaimana perusahaan menciptakan produk yang tepat untuk pasar sasaran. Berkaitan dengan produk adalah pemberian merek, pengemasan, jaminan, pengembangan produk baru, kualitas produk dan lini produk yang ada, (2) Tempat: Tempat adalah bagaimana perusahaan membuat produk/jasanya tersedia dalam jumlah dan lokasi yang tepat ketika konsumen memerlukan produk/jasa tersebut. Untuk lebih sederhana, tempat disini dapat 
dipahami sebagai saluran distribusi yang akan digunakan oleh perusahaan dalam mendistribusikan produknya. Berkaitan dengan tempat adalah wholesaler (termasuk distributor, pedagang besar), retailer (pengecer), dan logistik, (3) Promosi: Promosi adalah bagaimana perusahaan mengkomunikasikan produk/jasanya kepada saluran distribusi dan pasar sasarannya untuk mempengaruhi sikap dan perilaku mereka. Promosi dibedakan menjadi 3, yaitu penjualan pribadi (personal selling), penjualan massa (mass selling), dan promosi penjualan (sales promotion), (4) Harga: Harga adalah sejumlah uang yang perlu dibayarkan konsumen untuk mendapatkan tawaran perusahaan. Jika perusahaan melihat harga sebagai pendapatan, maka konsumen melihat harga sebagai biaya. Yang perlu diperhatikan adalah tujuan penetapan harga, kebijakan harga yang digunakan, dan bagaimana menetapkan harga di dunia bisnis.

\subsection{Komunikasi Pemasaran Terpadu}

\subsubsection{Definisi Komunikasi Pemasaran} Terpadu

Sebuah konsep perencanaan komunikasi terpadu adalah mengenali nilai tambah dari perencanaan mendalam yang mengevaluasi peran strategis dari berbagai disiplin komunikasi seperti periklanan, respon langsung, sales promosi, dan hubungan masyarakat dan menggabungkannya untuk menghasilkan dampak komunikasi yang penuh dengan kejelasan, konsisten, dan maksimal (American Association of Advertising Agencies)

Pendekatan yang digunakan adalah "gambar keseluruhan" yang mengenali seluruh aktivitas perusahaan seperti media iklan, harga, publisitas, penjualan promosi, penjualan langsung, dan lokasi di mana produk dijual. Contohnya, harga mahal menyimbolkan kualitas, bentuk produk, kemasan, nama merek, bahkan citra toko juga berperan terhadap komunikasi pemasaran. Konsep komunikasi pemasaran terpadu adalah menyatukan beberapa komponen komunikasi pemasaran untk menyampaikan pesan pemasaran kepada konsumen sehingga dampak yang diingikan lebih maksimal. Komunikasi pemasaran muncul karena ada perkembangan pada dunia sebagai berikut (1) perubahan dari media tradisional ke media lainnya. Biaya yang mahal dan tidak efektif. Persaingan harga antara perusahaan menyebabkan perusahaan memilih untuk promosi harga (2) ada fragmentasi media massa menyebabkan munculnya media yang lebih kecil dan fokus, misalnya direct mail dan event sponsorship, (3) globalisasi menyebabkan 
jaringan perusahaan menggantikan pengecer. Dengan teknologi scanner, dikenali perilaku pembelian dan diputuskan menggunakan metode promosi yang lebih efektif yaitu sales promotion, (4) berkembangnya database marketing. Komputer menyebabkan berbagai data mulai psikografik, demografik, geografik, pola pembelian, pemilihan media dihimpun. Data ini mendukung metode direct marketing yang langsung pada target khalayak, (5) perubahan pada pembelian media. Harga yang semakin mahal menuntut adanya diskon yang lebih besar dan kontrol yang lebih ketat terhadap pembelian media (Duncan, 2003)

Sedangkan Belch and Belch (2003) menambahkan bahwa perubahan dunia khususnya di bidang periklanan dan promosi seperti (1) sulitnya melakukan komunikasi yang efektif dan efisien dengan audiens sangat berpengaruh terhadap kesuksesan sebuah merek, (2) dibutuhkan sebuah komunikasi pemasaran yang menarik bagi konsumen karena konsumen tidak lagi tertarik terhadap periklanan tradisional, (3) perkembangan teknologi yang melahirkan new media sehingga media tradisional tidaklah lagi menjadi media primadona untuk melakukan komunikasi pemasaran, (4) dibutuhkan strategi yang efektif yang efisien untuk mengelola pengeluaran pemasangan iklan di media yang sangat mahal sehingga pemasar lebih menyalurkan dana pemasaran mereka pada taktik komunikasi pemasaran lainnya.

\subsection{Komponen-Komponen Komunikasi} Pemasaran Terpadu.

\subsubsection{Periklanan}

Definisi periklanan adalah komunikasi non-personal mengenai produk, ide, jasa yang dibayar oleh sponsor. komunikasi non-personal berarti penggunaan media massa sebagai penyampai pesan kepada individu dalam skala besar. Kelemahannya adalah tidak umpan balik dari target khalayak dan pengiklan harus mempertimbangkan bagaimana konsumen menafsirkan iklan tersebut. Keuntungan periklanan adalah biaya yang murah untuk menjangkau khalayak massal. Selain itu, mampu membentuk citra dan daya tarik simbolik untuk produk-produk yang sulit bersaing dari atribut fungsional. Kelemahan periklanan adalah biaya yang sangat mahal untuk penempatan iklan di media serta sulit sekali untuk melakukan pengukuran umpan balik (Duncan, 2003)

\subsubsection{Direct Marketing}

Pemasaran langsung (direct marketing) menurut Principles of Marketing (Kotler Gary Armstrong, 1996) adalah pemasaran yang menggunakan berbagai media iklan 
untuk berinteraksi langsung dengan konsumen, biasanya menelepon konsumen untuk mendapat respons langsung. Pada direct marketing, organisasi berkomunikasi langsung dengan konsumen untuk membangkitkan respon dan transaksi. Ada berbagai aktivitas pada direct marketing seperti direct selling, telemarketing, iklan direct respons. Contohnya adalah Tupperware, penjualan alat-alat kesehatan di berbagai mall Jakarta. Direct marketing merupakan salah satu fungsi IMC yang terdiri dari front-end dan back end operations. Front-end menyusun harapan-harapan dari konsumen yang mencakup the offer (yakni segala sesuatu yang nyata maupun tidak dijanjikan oleh perusahaan guna mencapai perilaku pelanggan yang diinginkan perusahaan, misal: penawaran harga khusus, garansi), the database (mendapatkan data pelanggannya dan menggunakan data itu untuk penawaran selanjutnya) dan the respons (memberikan respon yang baik terhadap pelanggan, misal: dengan membuat toll-free-line untuk layanan customer) sedangkan back end berusaha mempertemukan harapan konsumen dengan produk, mencakup fulfillment (yakni membuat produk atau informasi yang diminta oleh konsumen cocok, efektif dan tepat waktu). Jadi konsep direct marketing telah mendasarkan kegiatan komunikasi pemasarannya pada database pelanggan yang telah mereka punya (Duncan, 2003)

\subsubsection{Sales Promotion}

Sales promotion merupakan aktivitas pemasaran yang memberikan nilai lebih atau insentif kepada armada penjualan, distributor, atau konsumen dan dapat merangsang pembelian langsung (Duncan, 2003) Definisi lainnya diberikan oleh Institute of Sales Promotion adalah sales promotion terdiri dari sejumlah taktik pemasaran untuk menambah nilai sebuah produk atau jasa untuk mencapai tujuan pemasaran dan penjualan (Horchover, 2002) Sales promotion dibagi dua menjadi consumer oriented dan trade-oriented activities. Consumer oriented ditujukan kepada konsumen dengan menggunakan kupon, sampel, potongan harga, kontes, undian berhadiah. Konsumen dibujuk untuk melakukan pembelian. Sedangkan trade-oriented activities ditujukan kepad agen, distributor dan pengecer. Potongan harga, kontes penjualan terbanyak, dan pameran dagang merupakan langkah penerapannya.

\subsubsection{Public Relations}

Publisitas merupakan komuikasi non personal mengenai organisasi, produk, jasa dan ide yang tidak dibayar langsung oleh sponsor. Bentuknya berupa berita, 
editorial, pengumuman. Publisitas ditujukan untuk membentuk kesadaran, pengetahuan, pendapat, dan perilaku. Teknik publisitas adalah news releases, konferensi pers, artikel feature, foto-foto, film dan videotape. Keuntungan publisitas adalah kredibilitas karena peninjau dianggap bebas pengaruh dari organisasi. Selain itu, biaya yang rendah karena tidak ditanggung oleh organisasi. Kerugiannya adalah berita yang negatif dapat merusak citra organisasi (Duncan, 2003). Lebih lanjut lagi, ada sebuah kekhususan public relations terhadap marketing yaitu marketing public relations (MPR). Marketing public relations merupakan penggunaan strategi dan taktik public relations untuk mencapai tujuan pemasaran. Tujuan MPR adalah untuk menciptakan awareness, merangsang penjualan, fasilitasi komunikasi dan mengembangkan hubungan antara konsumen, perusahaan dan brand. MPR adalah program atau kampanye yang komprehensif yang ditujukan kepada audiens utk mempengaruhi penjualan atau penggunaan produk dan jasa perusahaan. Penggunaan special event, publisitas dan teknik public relations untuk mempromosikan produk dan jasa (Harris \& Whalen, 2006)

\subsubsection{Personal Selling}

Personal selling adalah komunikasi pribadi tatap muka di mana penjual menyakinkan pembeli untuk membeli melalui kontak langsung atau telepon. Bersifat fleksibel karena dapat mengubah pesan yang disampaikan ketika menerima umpan balik pembeli. Personal selling adalah komunikasi dua arah di mana penjual menafsirkan keunggulan brand untuk menarik perhatian pembeli. Paradigma terbaru personal selling adalah (1) fokus terhadap konsumen mulai dari memperhatikan konsumen tanpa memandang konsumen lama atau baru, (2) menciptakan dan mengelola pengharapan konsumen, tidak hanya pada kinerja produk namun semua pelayanan, (3) meliputi pengiriman, tagihan, dan penggunaan produk, (4) melakukan analisis bisnis konsumen sehingga produk dapat meningkatkan profit dan penjualan konsumen, (5) melakukan analisis bisnis konsumen sehingga produk dapat meningkatkan profit dan penjualan konsumen (Duncan, 2003). Sedangkan Forysth dalam Marketing And Selling Professional Services menambahkan bahwa personal selling harus lebih persuasif, memiliki diferensiasi dibandingkan dari kompetitor dan persuasi dapat ditunjukkan dari client awareness dan pelayanan (Forsyth, 2003). 


\subsubsection{Event Marketing}

Event dan sponsorship dirancang untuk menciptakan keterlibatan dan meningkatkan dimensi experiental komunikasi pemasaran. Ketika perusahaan mengenali kesuksesan pengalaman untuk mengikat konsumen terhadap brand maka terjadi ledakan pada event marketing. Walaupun event berbeda dengan sponsorship tetapi dua konsep ini sering overlap karena banyak event yang disponsori. Event marketing memiliki definisi yaitu a significant situation or promotional happening that has a central focus and captures the attention and involvement of the target audience. Perusahaan dan organisasi nirlaba menggunakan event dengan beberapa alasan seperti (1) Melibatkan target audiences, (2) Untuk mengasosiasikan brand dengan orang, aktivitas dan gaya hidup tertentu, (3) Untuk menjangkau target audiences yang sulit dijangkau, (4) Untuk meningkatkan brand awareness, (5) Untuk menyediakan dasar brand publicity. Events memiliki dampak yang lebih besar dibandingkan dengan fungsi komunikasi pemasaran lainnya. Karena event bersifat melibatkan atau involving. Sebuah event lebih diingat dan memberikan motivasi dibandingkan passive brand messages seperti periklanan, karena konsumen yang hadir melakukan partisipasi dan menjadi bagian dari event. Events dapat digunakan untuk melakukan brand positioning dengan melakukan asosiasi dengan aktivitas tertentu seperti Olimpiade, Piala Dunia dan lain sebagainya. Karena event memiliki fokus tunggal maka event menarik special audiences. Biasanya, event dipilih karena menjangkau brand target. Misalnya, untuk menjangkau pengguna sepeda motor, sebuah merek ban nasional menjadi sponsor kejuaraan otomotif nasional di beberapa daerah. Tujuannya adalah membangun kesadaran akan merek ban tersebut sebagai salah satu ban merek nasional. Karena event memiliki nilai publisitas, event dan digunakan untuk menciptakan brand publicity, kemudian menolong untuk menciptakan brand awareness dan menolong brand untuk tetap selalu pada top of mind pada target audiences (Duncan, 2003).

\subsubsection{Sponsorships}

Definisi sponsorship adalah the financial support of an organization, person, activity in exchange for brand publicity and association. Sponsorship memberikan brand differentiation dan brand value. Sebagai contoh sponsorship, sebuah perusahaan rokok Indonesia asal Kudus yaitu Djarum menjadi sponsor untuk Indonesia Open, salah turnamen bulu 
tangkis internasional. Dengan meneken kontrak selama tiga tahun, mereka akan memberikan hadiah sebesar 600.000 U\$D pada Indonesia Open. Tujuan sponsorship ini adalah membuktikan bahwa Indonesia dapat menjadi tuan rumah turnamen bulu tangkis internasional dengan hadiah uang yang besar. Hal ini akan memberikan prestise bagi Indonesia pada komunitas bulu tangkis internasional. Sponsorship merupakan salah satu jalan untuk untuk mengembangkan asosiasi brand untuk mendorong citra yang diinginkan. Jika asosiasi tidak sesuai dengan brand image dan brand messages maka konsumen akan kebingungan. Misalnya, Djarum mensponsori turnamen bulu tangkis sesuai karena Djarum memiliki klub pelatihan bulu tangkis yang telah melahirkan bibit bibit bulu tangkis sejak lama.

\subsubsection{Customer Service}

Customer service merupakan pengikat brand relationship. Ketika konsumen memiliki pertanyaan atau masalah, ia akan menghubungi departemen pelayanan pelanggan. Bagaimana keluhan ditangani akan menentukan brand relationship. Konsumen tidak mengharapkan perusahaan akan sempurna namun mengharapkan bahwa masalah akan segera diatasi. Jika ya, maka konsumen akan menjadi loyal. Definisi customer service adalah an ongoing, companywide process that begins with the design of a product and continous through all operations of a company that directly and indirectly affect a customer. Customer service memiliki makna fungsional dan makna konseptual. Secara konseptual, customer service berarti sikap menolong yang harus dimiliki oleh setiap karyawan. Sedangkan fungsi customer service adalah menjawab pertanyaan dan mengatasi keluhan.

\section{PEMBAHASAN}

Penerapan komunikasi pemasaran terpadu pada sebuah merk di mulai dari analisis situasi meliputi anggaran dasar produk/jasa dan persaingan yang sejenis di pasar. Analisis ini dilengkapi dengan informasi pencapaian penjualan melalui pendekatan historis dan anggaran yang telah ditentukan sebelumnya. Analisis situasi juga dipertajam dengan disediakannya informasi mengeai keberhasilan yang telah dicapai dalam merebut pangsa pasar dan potensi pasar yang masih tersedia. Kemudian pemasar menetapkan tujuan pemasaran Memberikan arah, rentang waktu untuk aktivitas pemasaran, dan mekanisme untuk mengukur kinerja. Setelah tujuan pemasaran ditetapkan, harus diformulasikan, strategi pemasaran dan program pemasaran meliputi pemilihan 
target market dan keputusan dan perencanaan untuk empat elemen marketing mix. Setelah proses perencanaan dibentuk maka masuk ke dalam tahap implementasi program yaitu program-program untuk menerapkan strategi pemasaran, termasuk menentukan tugas dan tanggung jawab yang harus dikerjakan. Akhirnya tahap monitoring merupakan proses pemantauan dan evaluasi yang memberikan umpan balik sehingga kendali dapat dipelihara dan perubahan yang diperlukan untuk menghadapi situasi terbaru.

Sebuah program perencanaan komunikasi terpadu mengacu kepada program perencanaan komunikasi terpadu. Apabila kita ingin membuat sebuah perencanaan iklan terhadap merek, maka pertama yang harus dilakukan adalah melakukan sebuah penelitian periklanan untuk mengembangkan pesan apakah yang sesuai dengan target audiens. Hal ini disebabkan karena pengenalan konsumen akan menentukan strategi kreatif apakah yang akan menarik perhatian konsumen sehingga pesan yang disampikan akan efektif. Di sisi lain, pemahaman konsumen akan menentukan media manakah yang tepat untuk digunakan sebagai media pemasangan iklan. Hal ini didasarkan karena biaya belanja iklan yang sangat mahal saat ini.
Pada taktik lainnya yaitu public relations, bagaimanakah seorang wirausahawan mampu menerapkan berbagai taktik public relations yang ada untuk menimbulkan publisitas pada media. Sebuah taktik marketing public relations adalah bagaimana melakukan sebuah kegiatan yang menarik perhatian media kemudian muncul brand activities tersebut di media. Kekuatan public relations adalah kekuatan media yang dipercayai publik sebagai sumber informasi sekaligus media yang tepat untuk membentuk kesadaran, pengetahuan, pendapat, dan perilaku. Saat ini, public relations sering di lirik sebagai metode alternatif oleh pemasar karena dapat menekan biaya pemasangan iklan di media yang sangat besar.

Pada taktik pemasaran langsung atau direct marketing, pendekatan yang dilakukan adalah pendekatan langsung yang bertujuan untuk membangkitkan respon dan transaksi. Apabila memang sudah memungkinkan untuk membangun sebuah departemen direct marketing, sebuah pelatihan yang komprehensif harus dilakukan untuk membangun product knowledge, database pelanggan dan lain sebagainya. Sayangnya saat ini, praktek pengelolaan database pelanggan di Indonesia melanggar prinsip privacy di mana database pelanggan diperjualbelikan secara bebas. Selain itu, konsep back end 
berupa pelayanan pelanggan masih kurang diperhatikan secara serius di mana pelanggan yang komplain tidaklah mendapatkan pelayanan yang prima. Paradigma yang ada masihlah bagaimana mendapatkan pelanggan baru sebanyak mungkin namun sayangnya pelanggan lama cenderung tidak diperhatikan.

Tidak hanya direct marketing yang bertujuan untuk menimbulkan respon langsung pelanggan namun taktik sales promotion juga dapat digunakan. Sales promotion merupakan taktik pengurangan harga karena harga sering dianggap sebagai faktor penentu untuk pembelian. Harga yang murah merupakan idaman bagi para konsumen sehingga sales promotion sering menunjukkan efektivitasnya dengan meningkatkan tingkat penjualan. Di sisi lain, terlalu sering melakukan sales promotion dapat menghancurkan niat pembelian karena konsumen lebih suka menunggu masa sales promotion sehingga penjualan di masa-masa non sales promotion dapat saja menjadi terganggu.

Taktik komunikasi pemasaran selanjutnya adalah personal selling di mana terjadi komunikasi tatap muka untuk penjualan melalui kontak langsung atau telepon. Melalui penjelasan sales, dapat saja terjadi penjualan yang merupakan jawaban kebutuhan konsumen. Saat ini, layanan perbankan dan asuransi di Indonesia merupakan perusahaan terdepan yang aktif menggunakan personal selling namun sayangnya pada prakteknya penerapannya cenderung mengganggu privasi konsumen. Tidak jarang konsumen berulangkali di telepon untuk penawaran produk yang sama. Dibutuhkan sebuah kajian lebih mendalam mengenai efektivitas personal selling ini di mana terjadi penjualan namun tidak bersifat mengganggu privasi konsumen.

Pendekatan untuk meningkatkan interaksi dengan konsumen dapat di capai melalui event dan sponsorship. Pada sebuah event, tujuan akhir yang ingin di capai adalah menciptakan keterlibatan konsumen dengan brand dan efek pengalaman yang positif pada konsumen terhadap brand sehingga konsumen memiliki pengalaman dan kesan yang positif. Sebuah event yang menarik juga akan menarik publisitas sehingga memiliki kemungkinan untuk terpapar pada sebuah media. Sponsorship merupakan pemberian sejumlah uang pada sebuah event mulai dari event olahraga, musik, film dan lain sebagainya sehingga kemungkinan besar brand tersebut memiliki paparan publisitas akan meningkat. Akan lebih baik lagi, event yang disponsori adalah sebuah event yang memiliki tingkat awareness yang baik dan memiliki fans base yang besar. 
Pada taktik-taktik komunikasi pemasaran di atas menekankan bagaimana mencari konsumen baru sebagai sumber pemasukan. Tidak jarang, konsumen yang sudah ada cenderung mendapatkan perlakuan yang berbeda padahal konsumen lama merupakan konsumen yang loyal, tidak lagi membutuhkan perkenalan merek bahkan cenderung membeli merek yang sudah ada sebagai pemenuhan kebutuhan mereka. Disinilah pelayanan pelanggan berfungsi untuk mempertahankan pelanggan. Apabila pelanggan memiliki keluhan terhadap merek yang ada, pelayanan pelanggan menjawab permasalahan, melakukan tindaklanjut dan memastikan bahwa permasalahan yang ada terpecahkan. Kepuasan pelanggan merupakan hal yang harus terus menerus dipertahankan sehingga mereka terus menerus menjadi konsumen yang loyal terhadap merek.

\section{KESIMPULAN DAN SARAN}

Dalam membangun merek yang dimilikinya seorang wirausahawan harus memperhatikan konsep pemasaran yang ada. Perencanaan produk, harga jual, lokasi penjualan sampai promosi merupakan konsep dasar. Sebuah produk yang memenuhi kebutuhan pelanggan, memiliki harga yang sesuai dengan daya beli konsumen, lokasi yang tepat sebagai tempat penjualan harus di dukung oleh strategi dan taktik promosi yang tepat.

Hambatan yang dihadapi pada promosi adalah rendahnya kepercayaan konsumen terhadap iklan, perkembangan teknologi informasi dan komunikasi yang melahirkan new media dan menggeser old media sebagai media yang efektif sebagai media promosi, biaya pemasangan promosi yang sangat besar dan sulitnya untuk mengukur umpan balik efektivitas pemasaran.

Melalui komunikasi pemasaran terpadu inilah, sebuah strategi komunikasi pemasaran yang bertujuan meningkatkan efektivitas dan efisiensi komunikasi pemasaran. Penggabungan berbagai taktik pemasaran mulai dari periklanan, public relations, direct marketing, personnal selling, event dan sponsorship serta customer service bertujuan untuk memikat konsumen mulai dari tingkat mengetahui merek, membangun kesan positif serta mempertahankan pelanggan yang ada. Harapan yang ada bahwa setiap wirausaha yang ada dapat menggunakan komunikasi pemasaran terpadu sebagai taktik promosi mereka yang disesuaikan dengan biaya anggaran promosi yang dimilikinya.

Sebagai pengembangan lebih lanjut, dibutuhkan sebuah penelitian lanjutan bersifat terapan yang meneliti wirausaha 
dan komunikasi pemasaran terpadu. Bagaimanakah efektivitas dan efisiensi komunikasi pemasaran terpadu dalam mengelola sebuah merek dan mengingat setiap merek berada pada kelas-kelas yang berbeda akan menjadi kajian menarik manakah taktik-taktik komunikasi pemasaran yang lebih efektif dan efisien.

\section{Daftar Pustaka}

1. Belch and Belch. (2003) Advertising And Promotion, $6^{\text {th }}$ Edition. McGrawHill.

2. Duncan, Tom. (2003). Principles Advertising And IMC. Sydney: Mcgraw-Hill, 2003

3. Forysth, Patrick. (2003) Marketing And Selling Professional Service. London: routledge.

4. Gungaphul, M., \& Boolaky, M. (2009). Entrepreneurship and marketing: an exploratory study in Mauritius. Journal of Chinese Entrepreneurship, 1(3), 209-226.

5. Harris, Thomas, L., Whalen, Patricia T,. (2006). The Marketer's Guide to Public Relations in

6. the $21^{s t}$. London: South-Western Educational Pub.

7. Horchover, David. (2002). Sales Promotion. London: Wiley.
8. Kariv,
Dafna. (2011).

Entrepreneurship, An International Introduction. London: Routledge.

9. Kotler, Phillip, Armstrong, Garry. (1996). Principles Of Marketing. New Jersey: Prentice-Hal.

10. Schultz, D., Tannenbaum, S. and Lauterborn, R. (1993). The New Marketing Paradigm: Integrated Marketing Communications. Lincolnwood, Illinois USA: NTC Business 